\title{
Studies of the Identification of Indigenous Varieties of Gladiolus for Commercial Traits
}

\author{
Ganesh B. Kadam ${ }^{1}$, P. Naveen Kumar ${ }^{1}$, T. N. Saha ${ }^{1}$, M. R. Dhiman ${ }^{2}$, \\ Nitika Gupta ${ }^{1}$ and K. V. Prasad ${ }^{1}$ \\ ${ }^{1}$ ICAR-Directorate of Floricultural Research, College of Agriculture Campus, \\ Shivajinagar, Pune 411005, India \\ ${ }^{2}$ ICAR-IARI, Regional Station, Katrain, Himachal Pradesh, India \\ *Corresponding author
}

\section{A B S T R A C T}

The impetus for Improvement of gladiolus in India resulted in many improved varieties which were bred under Indian conditions. To evaluate these indigenously developed

\section{Keywords}

Gladiolus, Morphology,

Evaluation, Indigenous

\section{Article Info}

Accepted: 18 July 2020 Available Online: 10 August 2020 varieties an experiment was conducted with 34 gladiolus varieties/cultivars at the Research Farm of Directorate of Floricultural Research, Pune. Based on the evaluation for important commercial traits, the cultivars Suchitra $(113.37 \mathrm{~cm})$, Arka Amar $(110.73 \mathrm{~cm})$, Melody Open $(105.50 \mathrm{~cm})$, Phule Ganesh $(102.84 \mathrm{~cm})$ and Phule Neelrekha $(102.54 \mathrm{~cm})$ were found superior for spike length. Maximum rachis length was recorded in cultivars Melody Open $(71.06 \mathrm{~cm})$, Sweta $(68.32 \mathrm{~cm})$, Phule Ganesh $(67.60 \mathrm{~cm})$, Suchitra $(65.92 \mathrm{~cm})$, Phule Neelrekha $(64.39 \mathrm{~cm})$ and Pusa Kiran $(62.22 \mathrm{~cm})$. The maximum number of florets was recorded in cultivars Pusa Urmi (19.56), Pusa Suhagin (19.55), Subhangani (19.00), Suryakiran (18.56), Ps Hybrid 40 (18.22) and Phule Neelrekha (18.11). Based on the evaluation for days required for spike initiation and first floret exhibiting colour, the varieties were classified into early, mid and late maturity groups. The varieties viz., Arka Kesar and Melody Open for early Arka Amar, Phule Neelrekha, Phule Ganesh and Arka Naveen for mid Pusa Suhagin and Pusa Sinduri for late cultivation could be selected in similar climactic conditions. These early, mid and late flowering varieties could be effectively utilized for crop planning and thereby profit can be maximized. Indigenous varieties with targeted effort towards making availability of quality planting material could help the small and marginal farmers in the region to improve their economic condition.

\section{Introduction}

Gladiolus (Tourn) L., a popular bulbous crop from Iridaceae family is grown extensively for cut flower production in India. Magnificent spikes with array of floret colours make it most preferred flower in garden display, floral arrangements, interior decorations, florist, etc. Gladiolus is comparatively easy to grow under open field conditions. Globally, it is ranked as fifth most important cut flower in International trade (Balaram and Janakiram, 2009). The increased demand for quality flowers in 
market, cultivated area under new gladiolus cultivars is increasing in India which is about 9.37 thousand ha with a production of 707 million spikes (NHB, 2013). Novel colours, forms and unique arrangements of florets on spikes are the most desired traits in the market and consumer preference or market acceptability is highly dynamic. Due to this every year, large number of varieties are being developed and added in Indian as well as in the international markets. With diverse agro-ecological conditions in India, gladiolus can be cultivated year-round. In India gladiolus is grown in most of the states like West Bengal, Madhya Pradesh, Maharashtra, Chhattisgarh, Assam, Uttarakhand, Karnataka, Haryana, Uttarakhand, Telangana, Manipur, Sikkim, Uttar Pradesh, Gujarat, Delhi, Goa, etc with a production value of 174.63 thousand tonnes (NHB, 2016). The improved gladiolus cultivars offer a diversity of colours, shapes, and sizes which makes it popular among the farmers for growing in open conditions. Due to the increased demand for novel cultivars and with improved quality, new cultivars were being regularly Introduced into the country. But often these introduced cultivars do not perform well under the local growing conditions and were mostly susceptible to dreaded diseases like fusarium under Indian conditions. Looking into the growing demand for novel cultivars the systematic varietal improvement programme was started in India in early 1970 with the start of All India Coordinated Research Project on Floriculture (AICRP on Floriculture-1971) by ICAR. As a result of that, we have a large number of varieties developed indigenously. As these varieties were bred in different agro-climatic conditions of India they are acclimatized for growing across the country. Therefore, efforts were made to evaluate the performance of these indigenous varieties for various morphological traits.

\section{Materials and Methods}

The experiment was carried out during 201718 and 2018-19 at research farm of Directorate of Floricultural Research, Pune. Healthy and uniform sized corms $(4.5-5.0 \mathrm{~cm})$ were planted at $5-7 \mathrm{~cm}$ depth at a spacing of $20 \mathrm{~cm} \times 20 \mathrm{~cm}$ in a randomized block design with three replications. The 34 indigenous gladiolus varieties included in experiment were, viz., Arka Aayush, Arka Amar, Arka Darshan, Arka Gold, Arka Kesar, Arka Kumkum, Arka Manoroma, Arka Naveen, Arka Poonam, Arka Sapna, Arka Tilak, Aarti, Bindiya, Chandani, Dhanvantari, Gulal, Gunjan, IIHR-11, IIHR-12, Punjab Down, PS. Hybrid, Phule Ganesh, Phule Neelrekha, Punjab Glad-2, Punjab Glance, Punjab Lemon Delight, Punjab Pink Elegance, Pusa Kiran, Pusa Sinduri, Pusa Suhagin, Shobha, Pusa Shubham, Solan Shringar, Suchitra, Suryakiran, Swarnima, Sweta, Tambri, UHFS Glos HB-11-10 and Urmi. Standard cultural practices were followed during the cropping season. The data were recorded on five randomly selected plants from each genotype in three replications. The data were subjected to statistical analysis using WAPS-1.0 (Web Based Agricultural Statistics Software Package developed by ICAR-CCARI, Goa).

\section{Results and Discussion}

The evaluation of indigenous gladiolus varieties (34 nos.) revealed that they varied significantly for growth and flowering characters (Table 1), which offers scope for further strengthening of breeding in gladiolus. Gladiolus (being highly heterozygous and vegetatively propagated) has potential for selection of desired traits like longer spikes, more number of spikes per corm, more number of florets per spike and higher multiplication ability. The data presented in Table 1 revealed that there is significant variation in gladiolus varieties under study. 
The plant height is directly related to the spike length which is the most economical trait in gladiolus. Plant height varied significantly and ranged from $70.80 \mathrm{~cm}$ (Pusa Shrijana) to $126.60 \mathrm{~cm}$ (Suchitra). The varieties, namely, Suchitra $(126.60 \mathrm{~cm})$, Arka Amar (119.25), Melody Open (113.16), Phule Ganesh (110.82), Phule Neelrekha (108.51), Pusa Urmi (108.50), Sweta (106.36), Pusa Suhagin (104.66) and Arka Naveen (103.04) were found significantly vigorous in growth than other varieties. Significantly shorter plant height was observed in varieties viz., Pusa Srijana $(70.80 \mathrm{~cm})$, Pusa Shubham $(78.10 \mathrm{~cm})$, Gulal $(78.62 \mathrm{~cm})$, Swarnima $(79.68 \mathrm{~cm})$, Bindiya $(82.36 \mathrm{~cm})$, Shahanoda (85.62 cm), Punjab Lemon Delight (87.04), Darshan $(87.90 \mathrm{~cm})$ and Gunjan $(88.00 \mathrm{~cm})$. The taller varieties can be used for cut flower production whereas shorter varieties could be utilized in landscaping and garden decoration as suggested by Cartor et al (2010). However, wide variation in growth characters, is probably due to genetic constitution of the varieties influenced by the growing environment. The present findings are in conformity with the reports of Swaroop, (2010) and Kadam et al., (2014) in gladiolus.

Spike length is the most desired trait for commercial cut flower production therefore, it is important to obtain varieties with long and quality spikes. Longer spikes certainly fetch better market price as well as good storage life. The spike length of varieties studied ranged between $57.69 \mathrm{~cm}$ (Pusa Srijana) to $113.37 \mathrm{~cm}$ (Suchitra). Significantly longer spike length was recorded in varieties viz., Suchitra (113.37 cm), Arka Amar (110.73 $\mathrm{cm})$, Melody Open $(105.50 \mathrm{~cm})$, Phule Ganesh (102.84 cm) and Phule Neelrekha $(102.54 \mathrm{~cm})$ whereas, significantly shorter spike length was recorded in Pusa Srijana $(57.69 \mathrm{~cm})$, Pusa Shubham $(68.12 \mathrm{~cm})$, Swarnima $(69.68 \mathrm{~cm})$, Gulal $(72.13 \mathrm{~cm})$, Bindiya $(72.91 \mathrm{~cm})$ and Darshan $(76.29 \mathrm{~cm})$.
Varieties with longer spike length would make an excellent cut flower for flower arrangements and exhibition as suggested by Cantor et al., (2010) and Swaroop et al., (2017).

Rachis length, number of florets per spike, internodal length and floret diameter were significantly different in indigenous varieties. These traits are highly important for overall aesthetic look of spike. Proportionately arranged florets on spike would fetch better price in the market. The maximum rachis length was recorded in cultivars, Melody Open $(71.06 \mathrm{~cm})$, Sweta $(68.32 \mathrm{~cm})$, Phule Ganesh $(67.60 \mathrm{~cm})$, Suchitra $(65.92 \mathrm{~cm})$, Phule Neelrekha $(64.39 \mathrm{~cm})$ and Pusa Kiran $(62.22 \mathrm{~cm})$. The maximum number of florets were recorded in cultivars Pusa Urmi (19.56), Pusa Suhagin (19.55), Subhangani (19.00), Suryakiran (18.56), Ps Hybrid 40 (18.22) and Phule Neelrekha (18.11). Floret diameter ranged between 5.83 to $10.94 \mathrm{~cm}$. Maximum floret diameter was recorded in Aarti (10.94 $\mathrm{cm})$, Phule Ganesh (10.83 cm), Tambri $(10.61 \mathrm{~cm})$, Melody Open $(10.50 \mathrm{~cm})$ and Sweta $(10.06 \mathrm{~cm})$. The internodal length significantly varied in indigenous varieties and ranged between $3.44 \mathrm{~cm}$ in Pusa Shrijana to $6.74 \mathrm{~cm}$ in Phule Ganesh. The variation in different characters among varieties might be due to genetic traits and the effect of prevailing environmental conditions as suggested by Kadam et al., (2014), Rani et al., (2007) and Negi et al., (2014).

Genetically gladiolus leaves are not having much variation and are typically swordshaped medium green upright leaves. Number of leaves ranged between 6.11 in Pusa Shrijana to 11.00 in Phule Neelrekha. The leaf length also varied significantly and ranged from $33.82 \mathrm{~cm}$ in Pusa Subham to $53.39 \mathrm{~cm}$ in Tambri. Leaf width was ranged from 2.97 $\mathrm{cm}$ in Pusa Srijana to $5.31 \mathrm{~cm}$ in Phule Ganesh. 
Table.1 Performance of indigenously developed gladiolus varieties under Pune conditions

\begin{tabular}{|c|c|c|c|c|c|c|c|c|c|c|}
\hline $\begin{array}{l}\text { S. } \\
\text { No. }\end{array}$ & Variety Name & $\begin{array}{c}\text { Plant } \\
\text { height }\end{array}$ & $\begin{array}{l}\text { No. of } \\
\text { florets }\end{array}$ & $\begin{array}{l}\text { No. of } \\
\text { Leaf }\end{array}$ & $\begin{array}{c}\text { Spike } \\
\text { Length }\end{array}$ & $\begin{array}{l}\text { Rachis } \\
\text { Length }\end{array}$ & $\begin{array}{c}\text { Leaf } \\
\text { Length }\end{array}$ & $\begin{array}{c}\text { Leaf } \\
\text { width }\end{array}$ & $\begin{array}{c}\text { Flower } \\
\text { diameter }\end{array}$ & $\begin{array}{l}\text { Internodal } \\
\text { length }\end{array}$ \\
\hline 1 & Arka Amar & 119.25 & 16.56 & 10.45 & 110.73 & 56.80 & 51.33 & 4.17 & 8.94 & 5.55 \\
\hline 2 & Arka Keshar & 99.20 & 15.22 & 9.11 & 86.36 & 49.01 & 43.61 & 4.49 & 9.83 & 4.25 \\
\hline 3 & Arka Naveen & 103.04 & 16.00 & 8.00 & 93.73 & 46.97 & 46.69 & 4.23 & 8.83 & 5.23 \\
\hline 4 & Aarti & 99.33 & 15.89 & 8.33 & 88.31 & 44.89 & 49.86 & 4.89 & 10.94 & 6.08 \\
\hline 5 & Bindiya & 82.36 & 14.34 & 7.00 & 72.91 & 58.18 & 52.58 & 3.10 & 9.05 & 3.67 \\
\hline 6 & Chandani & 99.08 & 14.89 & 6.34 & 86.23 & 45.17 & 44.84 & 3.88 & 8.72 & 4.62 \\
\hline 7 & Darshan & 87.90 & 13.33 & 8.78 & 76.29 & 49.67 & 42.27 & 3.17 & 6.61 & 6.39 \\
\hline 8 & Dhanvantari & 94.58 & 13.78 & 8.22 & 82.39 & 56.25 & 45.27 & 3.18 & 9.39 & 4.88 \\
\hline 9 & Gulal & 78.62 & 11.33 & 7.22 & 72.13 & 43.38 & 40.24 & 3.98 & 8.39 & 5.14 \\
\hline 10 & Gunjan & 88.00 & 13.33 & 8.33 & 78.37 & 44.47 & 44.31 & 4.88 & 9.61 & 3.65 \\
\hline 11 & Melody Open & 113.16 & 14.33 & 7.78 & 105.50 & 71.06 & 52.43 & 4.52 & 10.50 & 6.43 \\
\hline 12 & Phule Ganesh & 110.82 & 16.11 & 8.67 & 102.84 & 67.60 & 48.57 & 5.31 & 10.83 & 6.74 \\
\hline 13 & Phule Neelrekha & 108.51 & 18.11 & 11.00 & 102.54 & 64.39 & 48.74 & 4.00 & 8.61 & 6.15 \\
\hline 14 & Ps Hybrid 40 & 98.69 & 18.22 & 7.67 & 87.74 & 40.70 & 40.06 & 4.03 & 9.17 & 5.79 \\
\hline 15 & Punjab Dawn & 89.75 & 14.67 & 7.33 & 78.74 & 45.32 & 46.13 & 4.28 & 8.72 & 4.78 \\
\hline 16 & Punjab Glance & 88.53 & 14.89 & 7.11 & 79.08 & 46.44 & 52.38 & 4.59 & 8.39 & 5.98 \\
\hline 17 & Punjab Glad-1 & 100.03 & 15.11 & 8.00 & 88.20 & 43.30 & 48.61 & 4.12 & 9.50 & 5.89 \\
\hline 18 & Punjab Lemon Delight & 87.04 & 13.67 & 6.44 & 79.39 & 45.53 & 37.66 & 4.60 & 9.61 & 6.03 \\
\hline 19 & Punjab Morning & 94.98 & 14.00 & 6.78 & 86.57 & 49.40 & 45.66 & 3.86 & 8.72 & 5.04 \\
\hline 20 & Punjab Pink Elegance & 100.81 & 17.22 & 7.22 & 90.92 & 40.58 & 42.41 & 3.99 & 8.39 & 5.76 \\
\hline 21 & Pusa Kiran & 88.71 & 12.67 & 8.00 & 79.66 & 62.22 & 47.12 & 4.03 & 5.83 & 3.97 \\
\hline 22 & Pusa Shrijana & 70.80 & 8.56 & 6.11 & 57.69 & 47.13 & 34.74 & 2.97 & 8.83 & 3.44 \\
\hline 23 & Pusa Subham & 78.10 & 13.33 & 7.45 & 68.12 & 35.08 & 33.82 & 3.99 & 8.50 & 5.96 \\
\hline 24 & Pusa Suhagan & 104.66 & 19.55 & 7.89 & 91.94 & 43.55 & 49.51 & 3.97 & 8.61 & 5.79 \\
\hline 25 & Pusa Urmi & 108.50 & 19.56 & 8.89 & 95.95 & 51.13 & 47.13 & 3.92 & 9.61 & 5.81 \\
\hline 26 & Shabnam & 94.66 & 12.78 & 8.56 & 85.68 & 47.09 & 37.26 & 3.30 & 6.94 & 4.52 \\
\hline 27 & Shahanoda & 85.62 & 15.55 & 8.33 & 77.52 & 50.81 & 49.63 & 3.87 & 6.50 & 4.41 \\
\hline 28 & Subhangani & 101.75 & 19.00 & 8.33 & 89.05 & 49.41 & 49.19 & 4.84 & 9.39 & 6.07 \\
\hline 29 & Suchitra & 126.60 & 16.88 & 10.56 & 113.37 & 65.92 & 49.15 & 3.84 & 9.44 & 6.72 \\
\hline 30 & Suryakiran & 99.89 & 18.56 & 7.00 & 88.19 & 42.39 & 45.63 & 4.08 & 9.87 & 5.87 \\
\hline 31 & Swarnima & 79.68 & 13.43 & 6.56 & 69.68 & 51.97 & 37.64 & 3.57 & 7.95 & 3.85 \\
\hline 32 & Sweta & 106.36 & 13.67 & 7.67 & 84.01 & 68.32 & 46.37 & 3.83 & 10.06 & 4.82 \\
\hline 33 & Tambri & 101.62 & 15.78 & 7.00 & 91.54 & 50.08 & 53.39 & 4.72 & 10.61 & 5.65 \\
\hline 34 & UHFS G105HB-11-10 & 99.89 & 15.33 & 7.11 & 89.66 & 46.98 & 42.05 & 5.00 & 8.61 & 5.91 \\
\hline \multicolumn{2}{|r|}{ CV } & 6.328 & 9.307 & 8.014 & 7.748 & 8.214 & 5.714 & 7.131 & 7.385 & 7.429 \\
\hline \multicolumn{2}{|r|}{ CD $(\mathrm{p}<0.05)$} & 9.986 & 2.301 & 1.035 & 10.891 & 6.78 & 4.237 & 0.476 & 1.075 & 0.644 \\
\hline
\end{tabular}


Table.2 Classification of varieties based on days required for sprouting

\begin{tabular}{|c|c|c|}
\hline Sr no. & $\begin{array}{l}\text { Days required } \\
\text { for sprouting }\end{array}$ & Varieties \\
\hline 1. & $9-12$ & $\begin{array}{l}\text { Arka Amar, Chandani, Dhanvantari, Punjab Down, P.S. } \\
\text { Hybrid, Phule Ganesh, Shahanoda, Arka Naveen, } \\
\text { Melody Open, Phule Neelrekha, Punjab Glance, } \\
\text { Pusa Shubham, Suryakiran, Pusa Suhagin and Urmi }\end{array}$ \\
\hline 2. & $13-16$ & $\begin{array}{l}\text { Sweta, Gunjan, Shobha, Solan Shringar, UHFS Glos } \\
\text { HB-11-10, Arka Darshan and Arka Kesar }\end{array}$ \\
\hline 3. & $17-20$ & $\begin{array}{l}\text { Gulal, Suchitra, Swarnima, Aarti, Punjab Pink Elegance } \\
\text { and Pusa Sinduri }\end{array}$ \\
\hline 4. & $21-24$ & Bindiya, Pusa Kiran, Tambri and Punjab Lemon Delight \\
\hline
\end{tabular}

Table.3 Classification of varieties based on days required for spike initiation

\begin{tabular}{|r|l|l|}
\hline $\begin{array}{l}\text { Sr } \\
\text { no. }\end{array}$ & $\begin{array}{l}\text { Days required for } \\
\text { spike initiation }\end{array}$ & Varieties \\
\hline 1. & $45-55$ & $\begin{array}{l}\text { Dhanvantari, Gulal, Pusa Shubham, Melody Open, } \\
\text { Shahanoda, Chandani, Punjab Glance, Arka Kesar, } \\
\text { Punjab Dawn, Shobha, Arka Darshan, P.S. Hybrid }\end{array}$ \\
\hline 2. & $56-65$ & $\begin{array}{l}\text { Aarti, Phule Neelrekha, Sweta, Urmi, Suchitra, Gunjan, } \\
\text { Swarnima, UHFS Glos HB-11-10, Punjab Lemon } \\
\text { Delight, Suryakiran, Arka Amar, Arka Naveen, Punjab } \\
\text { Pink Elegance, Bindiya, Pusa Kiran, Tambri and Phule } \\
\text { Ganesh }\end{array}$ \\
\hline 3. & $66-75$ & \begin{tabular}{l} 
Pusa Sinduri, Pusa Suhagin and Solan Shringar \\
\hline
\end{tabular} \\
\hline
\end{tabular}

Table.4 Classification of varieties based on days required for first floret colour appearance

\begin{tabular}{|r|l|l|}
\hline $\begin{array}{l}\text { Sr } \\
\text { no. }\end{array}$ & $\begin{array}{l}\text { Days required for } \\
\text { first floret colour } \\
\text { appearance }\end{array}$ & Varieties \\
\hline 1. & $55-65$ & $\begin{array}{l}\text { Dhanvantari Pusa Shubham, Gulal, Chandani, } \\
\text { Shahanoda, Punjab Glance, Punjab Dawn, PS. Hybrid, } \\
\text { Arka Kesar, Melody Open and Shobha }\end{array}$ \\
\hline 2. & $66-75$ & $\begin{array}{l}\text { Suchitra, UHFS Glos HB-11-10, Arka Darshan, Aarti, } \\
\text { Gunjan, Swarnima, Sweta, Phule Ganesh, Arka } \\
\text { Naveen, Punjab Lemon Delight, Arka Amar, Phule } \\
\text { Neelrekha, Bindiya, Pusa Kiran, Tambri and Urmi }\end{array}$ \\
\hline 3. & $76-85$ & $\begin{array}{l}\text { Pusa Suhagin, Solan Shringar, Pusa Sinduri and } \\
\text { Suryakiran }\end{array}$ \\
\hline
\end{tabular}


However, these variations might be due to genotype, environmental as well as some physiological factors. This finding is in accordance with Swaroop et al., (2016), Kumar and Misra (2011) and Kumar et al., (2011) in gladiolus.

\section{Days required for sprouting}

The data in table 2 reveal that days required for sprouting of the corms ranged between 923 days. The earliest sprouting of corms (9-12 days) were found in varieties Arka Amar, Chandani, Dhanvantari, Punjab Dawn, PS. Hybrid, Phule Ganesh, Shahanoda, Arka Naveen, Melody Open, Phule Neelrekha, Punjab Glance, Pusa Shubham, Suryakiran, Pusa Suhagin and Urmi. Whereas the varieties Bindiya, Pusa Kiran, Tambri and Punjab Lemon Delight took longer period for sprouting (21-24 days). The sprouting of gladiolus corms purely depends on the cultivar, level of dormancy and environmental conditions like available moisture in soil, temperature etc. The present findings are in conformity with findings of Sankari et al., (2012) Nazir and Dwivedi, (2006) and Dalal et al., (2006) in gladiolus.

\section{Days required for spike initiation}

Varieties producing earliest spikes are always in demand for commercial cultivation. The days required for spike initiation was ranged between 45 to 75 days. Varieties grouped under early category recorded spike initiation from 45 to 55 days and these include Shahanoda, Chandani, Punjab Glance, Arka Kesar, Punjab Dawn, Shobha, Arka Darshan and P.S. Hybrid. These were followed by majority of varieties that fall in mid category (56-65 days) viz., Aarti, Phule Neelrekha, Sweta, Urmi, Suchitra, Gunjan, Swarnima, UHFS Glos HB-11-10, Punjab Lemon Delight, Suryakiran, Arka Amar, Arka Naveen, Punjab Pink Elegance, Bindiya, Pusa
Kiran, Tambri and Phule Ganesh. There were few in late category (66-75 days) like Pusa Sinduri, Pusa Suhagin and Solan Shringar (Table 3). The early, mid and late varieties could be effectively utilized for staggered planting and maximum profit could be achieved. The present findings are in conformity with findings of Kadam et al., (2014) and Cantor et al., (2010) in gladiolus.

\section{Days required for first floret exhibiting colour}

The first floret colour appearance is the commercial harvesting stage of gladiolus spikes for longer distance market. This trait is directly related to the market price. Therefore, it's very important to have varieties with shortest time to reach at this stage and with timely harvesting could fetch better price in market. Days required for first floret showing colour ranging between 55-85 days. The varieties fall in early group (55-65 days) are Dhanvantari, Pusa Shubham, Gulal, Chandani, Shahanoda, Punjab Glance, Punjab Down, P.S. Hybrid, Arka Kesar, Melody Open and Shobha, mid group (66-75 days) are Suchitra, UHFS Glos HB-11-10, Arka Darshan, Aarti, Gunjan, Swarnima, Sweta, Phule Ganesh, Arka Naveen, Punjab Lemon Delight, Arka Amar, Phule Neelrekha, Bindiya, Pusa Kiran, Tambri and Urmi and in late group (76-85 days) are Pusa Suhagan, Solan Shringar, Pusa Sinduri and Suryakiran. Thus, the trait (first florets colour appearance) could be utilized effectively for planning of daily harvesting schedule and better postharvest as well as marketing management. The present findings are in accordance with findings of Naresh et al., (2015) and Swaroop et al., (2017) (Table 4).

In conclusion the indigenous gladiolus varieties have significant diversity of their morphological characteristics. Early mid and late varieties can be exploited for staggered 
planting and glut conditions in market could be avoided. Most of the indigenous varieties have unique colours, better spike length and more number of florets along with ability to adapt in local climatic conditions would make them excellent for commercial cultivation. Moreover, these indigenous varieties can be used for the future breeding program. With targeted efforts on production of quality planting material of these indigenous gladiolus varieties would help to increase the income of small and marginal farmers. The gladiolus varieties found suitable for early cultivation are Arka Kesar and Melody Open whereas, the varieties like Arka Amar, Phule Neelrekha, Phule Ganesh and Arka Naveen can be grown for mid group and for late cultivation Pusa Suhagin and Pusa Sinduri could be selected in similar climactic conditions.

\section{References}

Balaram, M.V. and Janakiram, T. 2009. Genetic variability in gladiolus genotypes for corm characters. Journal of Ornamental Horticulture, 12 (2): 123-126.

Cantor M., Buta E., Cristea G., Chis L M. 2010. Improvement of gladiolus varietal collection in order to use as genitors in breeding work. Bulletin UASVM Horticulture, 67(1): 318-323 Print ISSN 1843-5254; Electronic ISSN 1843-5394

Dalal S. R., Paithankar D. N., Anokar, Lande S. S. Response of gladiolus varieties to different planting dates under Akola condition. Ann. Plant Physiol. 2006; 20(1):137-138.

Kadam G. B., Kumar G., Saha T. N., Tiwari A. K., Kumar R. 2014. Varietal evaluation and genetic variability studies on gladiolus. Indian Journal of Horticulture, 71(3):379-384.

Kumar R and Misra R L. 2011. Studies on nitrogen application in combination with phosphorus or potassium on gladiolus cv. Jester Gold. Journal of Ornamental Horticulture, 68(4): 5359.

Kumar, P., Maurya, R.K., Chakraborty, B., Mer, R. and Misra, D.S. 2011. Genetic variability and correlation studies in Gladiolus hybrida L. under tarai conditions. Ann. Hort. 4: 140-46.

Naresh S., Dorajee Rao, A.V.D., Vijaya Bhaskar V. Uma Krishana, K. and Rao, M. Paratpara 2015. Evaluation of gladiolus (Gladiolus Hybrida L.) hybrids under coastal Andhra Pradesh conditions. Plant Archives, 15(1): 451454.

Nazir, M., Dwivedi V. K. 2006. Evaluation of gladiolus cultivars for cut flower production under Western Uttar Pradesh conditions. $J$ Asian Hort. 2(3):222-225.

Negi R, Kumar S. and Dhiman S. R. 2014. Evaluation of different cultivars of gladiolus (Gladiolus grandiflorus L.) suitable for low hills of Himachal Pradesh. Indian Journal of Scientific Research and Technology, 2(6):6-11.

NHB (2013). NHB Data Base 2012-13. Published by National Horticultural Board, Department of Agriculture and Cooperation, Government of India, New Delhi.

NHB (2016). NHB Data Base 2015-16. Published by National Horticultural Board, Department of Agriculture and Cooperation, Government of India, New Delhi.

Rani R., Prasad K. K, Rakesh Ranjan. 2007. Study of varietal performance in gladiolus. Orissa J Hort. 35(2):35-38.

Sankari, A., Anand, M. and Arulmozhiyan, R. 2012. Evaluation of gladiolus cultivars in Eastern Ghats of Tamil Nadu. $J$. Hortl. Sci., 7(2):206-208.

Swain, S., Rath, C.S. and Seithi, B.K. 2008. 
Evaluation of gladiolus cultivars for quality flowers and corm yield under Eastern Ghat in high land zone of Orissa. Orissa J. Hort., 36: 122-123.

Swaroop, K., Singh, K. P., Kumar, P. and Sindhu, S.S. 2017. Improvement and Performance of Gladiolus Hybrids for Flower Traits/ Novel Colour and Higher Corm multiplication. International Journal of Agriculture Innovations and Research 6(4): 4-7.
ISSN (Online) 2319-1473.

Swaroop, K., Singh, K.P., Kumar, P. and Janakiram, T. 2016. Genetic diversity and response of gladiolus (Gladiolus hybridus) hybrids for growth, flowering and corms traits under ecological conditions of Delhi. Indian Journal of Agricultural Sciences, 86 (12): 160612.

\section{How to cite this article:}

Ganesh B. Kadam, P. Naveen Kumar, T. N. Saha, M. R. Dhiman, Nitika Gupta and Prasad, K. V. 2020. Studies of the Identification of Indigenous Varieties of Gladiolus for Commercial Traits. Int.J.Curr.Microbiol.App.Sci. 9(08): 1671-1678.

doi: https://doi.org/10.20546/ijcmas.2020.908.192 